\title{
UM MUNDO SEM POBREZA: A EMPRESA SOCIAL E $O$ FUTURO DO CAPITALISMO
}

\section{Resenha do livro Um mundo sem pobreza: a empresa social e o futuro do capitalismo, de Muhammad Yunus}

São Paulo: Ática, 2008, 263p.

\section{Cassiano Ricardo Martines Bovo}

Muhammad Yunus se tornou famoso por ter criado o maior banco de microcrédito do mundo, o Grameen Bank, e por ter escrito o best-seller O banqueiro dos pobres. Desde o surgimento do banco em questão, o autor criou várias outras empresas, e essa empreitada redundou no recebimento do Prêmio Nobel da Paz, juntamente com o Grameen Bank.

Em Um mundo sem pobreza, Yunus volta a tratar do Grameen Bank, mas adiciona vários outros ingredientes que dão uma nova visão para a luta contra a pobreza. O livro está dividido em três partes e é constituído por 11 capítulos, além de um posfácio, que é a reprodução do seu discurso na cerimônia de entrega do Prêmio Nobel.

Na primeira parte, denominada "A promessa da empresa social", há exposta a sua ideia principal que vai permear todo o texto: trata-se da empresa social, vista como solução para superar a pobreza no mundo. Esta é voltada para a solução de problemas sociais e ambientais e opera como qualquer outro empreendimento convencional, envolvendo a necessidade de ser competitivo e estruturado da maneira mais eficiente possível. No entanto, esse tem uma diferença: não distribui dividendos aos acionistas. A ideia é que a empresa pague aqueles que a financiaram, mas o lucro, ao invés de ser distribuído, fica retido para investimento na própria companhia. Isso fica evidente na seguinte passagem:

* Mestre em Economia pela PUC-SP, doutor em Ciências Sociais pela PUC-SP, e-mail: cassiano. bovo@terra.com.br 
Assim, uma empresa social é projetada e dirigida como um empreendimento, com produtos, serviços, clientes, mercados, despesas e receitas: a diferença é que o princípio da maximização dos lucros é substituído pelo princípio do benefício social. Em vez de acumular o maior lucro financeiro possível — para ser desfrutado pelos investidores - , a empresa social procura alcançar objetivos sociais (p. 37).

Uma variante da empresa social é aquela que atua como uma EML (Empresa Maximizadora dos Lucros), nem sempre destinada a resolver problemas sociais, porém a propriedade é das pessoas pobres:

Nesse caso, o benefício social consiste no fato de que os dividendos e o crescimento do capital social produzidos pela EML servirão para beneficiar os pobres, ajudando-os a reduzir a pobreza ou até mesmo a sair dela completamente (...). Na realidade, o benefício social oferecido por esse tipo de empresa emana de sua propriedade (p. 42).

Uma vez elucidado o conceito de empresa social, o escritor amplia sua análise na segunda parte, intitulada "A experiência com o Grameen". No capítulo 3 ("A revolução do microcrédito"), é narrada a experiência do banco, na linha do livro $O$ banqueiro dos pobres, desde o seu surgimento, o seu funcionamento, além de uma avaliação do que já foi feito.

No capítulo 4 ("Do microcrédito à empresa social") são apresentadas as mais variadas empresas do grupo Grameen, que produzem desde tecidos a telefonia celular, em geral estruturadas na forma de empresa social. No capítulo 5 ("A batalha contra a pobreza: Bangladesh e o mundo"), mostra-se a pobreza em meio aos desastres naturais em Bangladesh e como esta vem diminuindo. Ao enfocá-la de que maneira poderia combatê-la, Muhammad Yunus depara com um assunto importante para quem estuda o tema, que é a definição de pobreza, dado que esta pode ser vista de várias maneiras; nesse sentido, ele cria uma lista de 10 pontos para conceituá-la. Um aspecto que merece reflexão, nessa parte, é a sua visão de que os pobres têm capacidade e habilidade para empreenderem, ao contrário do que pensam a maioria dos experts na questão, que entendem que o problema é que os pobres não têm habilidade e muitas vezes precisam ser treinados.

Nos capítulos 6 e 7 ("Deus está nos detalhes" e "Um copo de yogurte de cada vez"), Yunus relata a parceria estabelecida entre o grupo Grameen e a Danone, resultando em uma empresa social chamada Grameen Danone. 
O objetivo é a fabricação de um yogurte a um preço que possa ser acessível aos mais pobres, que enriqueça a alimentação das crianças. Vários estudos e testes foram realizados, e a produção se iniciou em uma fábrica que ainda atende a uma pequena região de Bangladesh, porém com perspectivas de construção de mais fábricas para levar o yogurte para todo o país.

A terceira parte é denominada "Em busca de um mundo sem pobreza". No capítulo 8 ("Ampliação do mercado"), a discussão gira em torno do questionamento de "onde vem o dinheiro para a empresa social?". Segundo Yunus, muita gente quer ajudar e pode se dispor ao financiamento da empresa social, inclusive várias fundações existentes no mundo. A criação da Grameen Danone mostra que uma empresa tradicional, até, pode ser uma boa fonte de financiamento. Crescendo a empresa social, um mercado de empresas desse tipo, com papéis e certificação, poderá ser criado. O papel do governo pode ser a renúncia a tributos e a criação de estudos de impacto social. Tratase de uma revolução no mercado de capitais que deverá ocorrer:

Com o tempo, surgirão cada vez mais instituições para amparar o desenvolvimento das empresas sociais. Precisaremos de sistemas formais de financiamento, e uma das muitas opções possíveis são os fundos mútuos, semelhantes ao Fundo Comunitário Danone. Entre as outras opções destacam-se a criação de novos bancos comerciais e de poupança especializados no financiamento de empresas sociais, o surgimento de investimentos sociais de risco e o nascimento de um mercado derivado dos investimentos nas empresas sociais. Os investidores poderão comprar e vender ações de empresas sociais, do mesmo modo que fazem com as ações das empresas convencionais. Com o tempo, todos esses mecanismos de financiamento e muitos outros acabarão se ajustando (p. 188).

No capítulo 9 ("Tecnologia da informação, globalização e transformação do mundo") é mostrado como as novas tecnologias podem ajudar os mais pobres, principalmente por meio da criação de uma organização que seria chamada de Centro de Iniciativas Internacionais para Soluções de TI e Erradicação da Pobreza. A rede a ser criada ajudaria os pobres a se unirem na luta contra a pobreza: "A Step seria uma rede dinâmica de instituições e pessoas ao redor do planeta, todas trabalhando em favor de metas comuns sistematicamente ordenadas, definidas e monitoradas por uma equipe administrativa" (p. 204). 
Já no capítulo 10 (“Os riscos da prosperidade”), a atenção recai para o "dilema do crescimento", que implica o fato de que o crescimento econômico dos países em desenvolvimento pode gerar agressão ao meio ambiente.

Finalmente, no capítulo 11 ("Colocando a pobreza nos museus"), atenta-se para a imaginação no sentido de se sonhar com um mundo sem pobreza, em que se propõe uma longa lista de metas que seria um “(...) processo de imaginar o mundo futuro do jeito que queremos...” (p. 231). O plano é a criação do que Yunus denomina grupos de ação social, podendo alguns até se tornar empresas sociais. A ideia desses grupos é a atuação em relação a algum problema relacionado à pobreza e ao meio ambiente.

Como se pode perceber, Yunus é otimista em relação ao combate à pobreza e, concordando-se ou não, o livro proporciona uma série de aspectos que alimentam o debate sobre o tema. 